\title{
Amino acid composition of hen's egg
}

\author{
By P. LUNVEN and C. Le CLEMENT De St MARCQ \\ Nutrition Division, FAO, Rome, Italy \\ AND E. CARNOVALE AND A. FRATONI \\ National Institute of Nutrition, Rome, Italy
}

(Received I August 1972-Accepted 23 fanuary 1973)

\begin{abstract}
1. Pooled samples of eggs from White Leghorn and New Hampshire hens given diets containing $\mathrm{I} 10$ and $200 \mathrm{~g}$ protein $/ \mathrm{kg}$ were analysed for their content of essential amino acids.

2. The amino acid composition of the hen's egg protein was not significantly affected by variations in breed and diet.

3. The estimated values for lysine, total sulphur-containing amino acids and tryptophan in egg protein were higher by $8.9,2.0$ and $8 \%$, respectively than those adopted for hen's egg by the FAO/WHO Expert Committee (FAO, 1965).

4. The isoleucine content of egg protein was found to be much lower ( $33^{8} \mathrm{mg} / \mathrm{g}$ nitrogen) than that reported by other workers.
\end{abstract}

The FAO/WHO Expert Group on Protein Requirements (FAO, 1965) agreed to adopt the essential amino acid pattern of the hen's egg protein as a reference standard. In evaluating dietary proteins, several workers have observed significant differences in the chemical score calculated from the amino acid pattern and nutritional value determined by biological tests. However, different workers (Block \& Mitchell, 1946-7; Rutgers University Bureau of Biological Research, 1950; Edwards, Carter \& Outland, 1955) have used different patterns of amino acids as reference standards and this partly explains the differences observed in dietary protein evaluation. References are available only to a few publications on the essential amino acid composition of hen's egg protein associated with variation in breed, the quality and quantity of protein in the diet and the environment of the hens.

\section{EXPERIMENTAL}

Two-month-old White Leghorn and New Hampshire hens were used. They were fed $a d l i b$. on diets containing $\mathrm{I} 1 \mathrm{O}$ and $200 \mathrm{~g}$ protein $/ \mathrm{kg}$ for a period of $\mathrm{I} 2$ months. The composition of the diet is shown in Table $\mathrm{r}$. The diets were supplemented with vitamins (Bird, 1947) and mineral salts (Briggs, Spivey, Keresztsesy \& Silverman, 1952). Both diets contained the same amount of sulphur-containing amino acids $\left(3^{\circ} \circ \mathrm{g}\right)$, lysine $\left(3^{\circ} \cdot \mathrm{g}\right)$, tryptophan $(\mathrm{I} \circ \mathrm{g})$ and arginine $(4 \cdot 5 \mathrm{~g})$ per $\mathrm{I} 6 \mathrm{~g}$ nitrogen.

The hens were divided into groups of ten and were housed either on deep litter or free range according to the following arrangement:

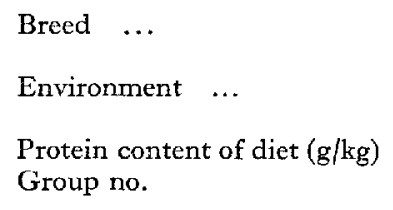

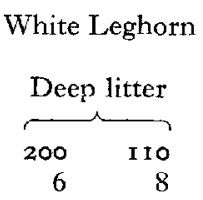

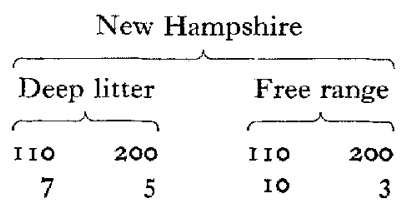


Table r. Composition of experimental diets $(\mathrm{g} / \mathrm{kg})$

\begin{tabular}{|c|c|c|}
\hline & \multicolumn{2}{|c|}{$\begin{array}{c}\text { Crude protein conte } \\
\qquad(\mathrm{N} \times 6.25)\end{array}$} \\
\hline & I IO & 200 \\
\hline Maize flour & 460 & 340 \\
\hline Wheat flour & 210 & 180 \\
\hline Oat flour & $\mathrm{r} 20$ & 120 \\
\hline Defatted soya-bean flour & & I60 \\
\hline Wheat bran & 80 & - \\
\hline Lucerne & 20 & 20 \\
\hline Skim-milk solids & 5 & I5 \\
\hline Maize oil & 35 & 35 \\
\hline Fish meal & 5 & 40 \\
\hline Powdered meat & 5 & 40 \\
\hline Vitamin-mineral mix* & 50 & 50 \\
\hline DL-methionine & 2 & - \\
\hline L-lysine hydrochloride & 2 & - \\
\hline Gelatin & 6 & - \\
\hline
\end{tabular}

The humidity and temperature varied from $5^{1}$ to $100 \%$ relative humidity and from $3^{\circ}$ to $34^{\circ}$, respectively.

The eggs were collected in trap cages, permitting the identification of the layer and the numbering of the eggs so that a statistically valid sample could be taken. The number and weights of the eggs and the quantity of diet consumed were recorded.

Every 2 weeks, six lots of ten eggs (one from each hen of each group) were selected from the eggs laid. The contents of the eggs from each lot were individually pooled, homogenized and freeze-dried.

The protein content and amino acid composition were determined for each sample and it was possible to carry out twenty-four determinations of protein content and seventeen determinations of amino acid content.

Total protein was determined by the Kjeldahl method (Association of Official Agricultural Chemists, 1965). The proteins were hydrolysed by conventional acid hydrolysis with $6 \mathrm{M}-\mathrm{HCl}$ in a sealed tube (Moore \& Stein, I95 I). One portion from each sample was hydrolysed separately for the determination of cystine as cysteic acid (Schram, Moore \& Bigwood, r954) and another was hydrolysed with $5 \mathrm{M}-\mathrm{NaOH}$ in a sealed tube for determination of tryptophan (Lunven, 1963). The amino acid content was determined with a Beckman-Spinco Model i $20 \mathrm{C}$ Amino Acid Analyser equipped with a Beckman Model 125 Automatic Digital Integrator. Each analysis was done in duplicate. The amino acid compositions of the yolks and whites of eggs from hens on deep litter were determined. Ten eggs from each group, selected as described, were frozen and their shells were removed. The yolks and whites were separated, weighed, stirred separately, homogenized and freeze-dried. The protein content and amino acid composition were determined for each sample. 
Table 2. Amino acid composition (mg/g nitrogen) of eggs from two breeds of hen, housed either on deep litter or free range and given diets of protein content $200 \mathrm{~g} / \mathrm{kg}(\mathrm{groups} 6,5,3)$ or I10 $g / k g$ (groups I0, 8, 7)

\begin{tabular}{|c|c|c|c|c|c|c|c|c|c|c|c|c|c|c|}
\hline \multirow[b]{4}{*}{ Amino acid } & \multirow{2}{*}{\multicolumn{4}{|c|}{$\begin{array}{c}\text { White Leghorn } \\
\text { Deep litter }\end{array}$}} & \multicolumn{8}{|c|}{ New Hampshire } & \multirow{4}{*}{$\begin{array}{c}\text { Mean } \\
\text { value }+\end{array}$} & \multirow{4}{*}{$\begin{array}{c}\text { FAO/ } \\
\text { WHO } \\
\text { egg } \\
\text { pattern } \\
\text { (FAO, } \\
\text { I965) }\end{array}$} \\
\hline & & & & & \multicolumn{4}{|c|}{ Deep litter } & \multicolumn{4}{|c|}{ Free range } & & \\
\hline & \multicolumn{2}{|c|}{ Group 8} & \multicolumn{2}{|c|}{ Group 6} & Grou & up 7 & Grou & ap 5 & Grou & גр го & Gro & up 3 & & \\
\hline & Value & $\mathrm{Cv}^{*}$ & Value & $\mathrm{Cv}^{*}$ & Value & $\mathrm{Cv}^{*}$ & Value & $\mathrm{CV}^{*}$ & Value & $\mathrm{Cv}^{*}$ & Value & $\mathrm{Cv}^{*}$ & & \\
\hline Lysine & 446 & $3 \cdot 0$ & 433 & $3 \cdot 7$ & 439 & $2 \cdot 5$ & $43^{8}$ & $2 \cdot 6$ & $44^{\circ}$ & $3 \cdot 2$ & 440 & $3 \cdot 3$ & 439 & 403 \\
\hline Histidine & I 43 & $5 \cdot 9$ & 139 & $4 \cdot 3$ & 143 & $5 \cdot 9$ & 140 & $4 \cdot 2$ & 146 & $5 \cdot 9$ & 139 & $5 \cdot 2$ & 142 & 一 \\
\hline Arginine & 380 & $3 \cdot 1$ & 376 & $3 \cdot 5$ & 379 & $3 \cdot 4$ & $3^{80}$ & $2 \cdot 6$ & $3^{84}$ & 3.0 & 379 & $2 \cdot 9$ & 380 & - \\
\hline Aspartic acid & 610 & $2 \cdot I$ & 613 & $2 \cdot 2$ & 609 & $2 \cdot 3$ & 6 II & $2 \cdot 9$ & 6 II & $2 \cdot 3$ & 610 & $2 \cdot 5$ & $6 \mathrm{II}$ & - \\
\hline Threonine & 290 & $3 \cdot I$ & 2,96 & $4 \cdot 4$ & 302 & $3 \cdot 6$ & 297 & $4 \cdot 3$ & 298 & $3 \cdot 2$ & 293 & $3 \cdot 6$ & 296 & 317 \\
\hline Serine & 447 & $3 \cdot 6$ & $45^{8}$ & $4 \cdot 2$ & 466 & $3 \cdot 8$ & 457 & $4 \cdot 8$ & 454 & $3 \cdot 8$ & 450 & 377 & 455 & - \\
\hline Glutamic acid & 823 & $2 \cdot I$ & 833 & I. 4 & 821 & $2 \cdot 6$ & 823 & $I \cdot 5$ & 824 & $2 \cdot I$ & 827 & $\mathrm{I} \cdot 8$ & 825 & - \\
\hline Proline & 242 & $4 \cdot 2$ & 233 & $2 \cdot 9$ & 244 & 49 & 237 & $4 \cdot 3$ & 239 & $3 \cdot 7$ & 237 & $4 \cdot 3$ & 239 & — \\
\hline Glycine & 197 & $2 \cdot 5$ & 198 & $2 \cdot 6$ & I 96 & $3 \cdot 4$ & 198 & 2.0 & I 96 & $2 \cdot 6$ & 197 & $2 \cdot 2$ & 197 & 一 \\
\hline Alanine & $34 \mathrm{I}$ & $\mathrm{I} \cdot 8$ & 344 & $2 \cdot 0$ & 342 & $2 \cdot 3$ & 340 & $I \cdot I$ & 340 & 2.0 & $34 \mathrm{I}$ & $2 \cdot 2$ & $34 \mathrm{I}$ & - \\
\hline Cystine & 159 & $7 \cdot 2$ & 157 & $9 \cdot 4$ & 160 & $5 \cdot 6$ & I 55 & $7 \cdot 4$ & I 56 & $6 \cdot I$ & 163 & $5 \cdot 3$ & 158 & I 49 \\
\hline Valine & 417 & $2 \cdot 9$ & 414 & $3 \cdot 8$ & 402 & $4^{2}$ & 419 & $3 \cdot 4$ & 412 & $2 \cdot 8$ & 414 & $4 \cdot 4$ & $4 \mathrm{~T} 3$ & 454 \\
\hline Methionine & 196 & $4 \cdot 2$ & 198 & $5 \cdot 5$ & 192 & $5 \cdot 2$ & I9I & $4 \div 9$ & 196 & $4^{\cdot I}$ & 199 & 6.8 & I95 & 197 \\
\hline Isoleucine & 340 & $3 \cdot 4$ & 335 & $3 \cdot 5$ & 332 & 3.7 & 343 & $4 \%$ & 334 & $3 \cdot 7$ & 343 & $5 \cdot 4$ & $33^{8}$ & 415 \\
\hline Leucine & 532 & $1 \cdot 9$ & 535 & $2 \cdot 7$ & 538 & $2 \cdot 1$ & 536 & $2 \cdot 4$ & 534 & $2 \cdot 2$ & 534 & $2 \cdot 4$ & 535 & 553 \\
\hline Tyrosine & $25 I$ & 4.0 & 253 & $5 \cdot I$ & 250 & $4^{\circ} 4$ & $25 I$ & $3 \cdot 6$ & 257 & $3 \cdot 9$ & 248 & $3 \cdot 3$ & 252 & 262 \\
\hline Phenylalanine & 328 & $4 \cdot 5$ & 330 & 3.5 & 328 & $4 \cdot 5$ & 324 & $3 \cdot 2$ & 318 & $4 \cdot 6$ & 326 & $3 \cdot 3$ & 326 & 365 \\
\hline Tryptophan & I08 & 9.0 & 105 & 8.6 & 107 & $8 \cdot 4$ & Iro & $9 \cdot 4$ & I I I & $8 \cdot 2$ & I IO & $7 \cdot 7$ & 108 & 100 \\
\hline \multirow{2}{*}{$\begin{array}{l}\text { Protein (mg/g } \\
\text { dry matter) }\end{array}$} & \multirow{2}{*}{\multicolumn{2}{|c|}{464}} & \multirow{2}{*}{\multicolumn{2}{|c|}{474}} & \multirow{2}{*}{\multicolumn{2}{|c|}{441}} & \multirow{2}{*}{\multicolumn{2}{|c|}{450}} & \multirow{2}{*}{\multicolumn{4}{|c|}{453}} & & \\
\hline & & & & & & & & & & & & & & \\
\hline
\end{tabular}

Table 3. Amino acid composition (mg/g nitrogen) of egg white from two breeds of hen, given diets of protein content $200 \mathrm{~g} / \mathrm{kg}$ (groups 6 and 5) or I Io $\mathrm{g} / \mathrm{kg}$ (groups 8 and 7 )

\begin{tabular}{|c|c|c|c|c|c|c|c|}
\hline \multirow[b]{2}{*}{ Amino acid } & \multicolumn{2}{|c|}{ White Leghorn } & \multicolumn{2}{|c|}{ New Hampshire } & \multicolumn{3}{|c|}{ Coefficient } \\
\hline & Group 8 & Group 6 & Group 7 & Group 5 & value & variation & (I970) \\
\hline Lysine & 359 & 394 & 368 & $39 \mathrm{I}$ & 378 & $4 \cdot 7 x$ & $4^{\mathrm{I}} 5$ \\
\hline Histidine & I I & I 37 & 135 & I 37 & 132 & $5 \cdot 84$ & I47 \\
\hline Arginine & 324 & 334 & 327 & $33^{6}$ & $33^{\circ}$ & I.65 & 357 \\
\hline Aspartic acid & 620 & 623 & 650 & 617 & 628 & $3 \cdot 59$ & 687 \\
\hline Threonine & 269 & 275 & 278 & 265 & 272 & $2 \cdot 26$ & 299 \\
\hline Serine & 456 & 409 & 441 & 410 & 429 & 5.08 & $45^{6}$ \\
\hline Glutamic acid & 874 & 879 & 855 & $87 \mathrm{I}$ & 869 & I. 55 & 937 \\
\hline Proline & 216 & 194 & 207 & 220 & 209 & $7 \cdot 70$ & 228 \\
\hline Glycine & 206 & 201 & 205 & 207 & 205 & 1.92 & 222 \\
\hline Alanine & 359 & $35 \mathrm{I}$ & 358 & 362 & 357 & $1 \cdot 50$ & $3^{80}$ \\
\hline Cystine & 185 & 174 & 186 & I 67 & 178 & $7 \cdot 45$ & I 50 \\
\hline Valine & $43 \mathrm{I}$ & 438 & $41 x$ & 436 & 429 & $2 \cdot 79$ & 301 \\
\hline Methionine & 236 & 240 & 253 & 230 & 240 & $4^{* 10}$ & 248 \\
\hline Isoleucine & 332 & 335 & 318 & 338 & $33 \mathrm{I}$ & $2 \cdot 58$ & $32 \mathrm{I}$ \\
\hline Leucine & 517 & 526 & 517 & 525 & 521 & $\mathrm{I} \cdot 56$ & 5 I 8 \\
\hline Tyrosine & 240 & 237 & 277 & 276 & 257 & $8 \cdot 29$ & 219 \\
\hline Phenylalanine & 386 & 384 & 342 & 358 & 368 & 4.97 & 372 \\
\hline Tryptophan & I2I & I 17 & 122 & 106 & I 6 & $6 \cdot{ }_{5}$ & - \\
\hline Protein (mg/g dry matter) & 845 & 852 & 840 & 829 & $84 \mathrm{I}$ & & \\
\hline
\end{tabular}


Table 4. Amino acid composition (mg/g nitrogen) of egg yolk from two breeds of hen, given diets of protein content $200 \mathrm{~g} / \mathrm{kg}$ (groups 6 and 5) or $110 \mathrm{~g} / \mathrm{kg}$ (groups 8 and 7 )

\begin{tabular}{|c|c|c|c|c|c|c|c|}
\hline \multirow[b]{2}{*}{ Amino acid } & \multicolumn{2}{|c|}{ White Leghorn } & \multicolumn{2}{|c|}{ New Hampshire } & \multicolumn{3}{|c|}{ Coefficient } \\
\hline & Group 8 & Group 6 & Group 7 & Group 5 & value & variation & $(1970)$ \\
\hline Lysine & 463 & 476 & 493 & 475 & 477 & $3 \cdot 85$ & 480 \\
\hline Histidine & I39 & 154 & 142 & 156 & 148 & $5 \cdot 50$ & 158 \\
\hline Arginine & 432 & 436 & $43^{8}$ & 430 & 434 & $I \cdot 72$ & 469 \\
\hline Aspartic acid & $6 \times 5$ & 607 & 614 & 616 & 613 & $I \cdot 44$ & 663 \\
\hline Threonine & $3 \pm 3$ & 307 & 309 & 325 & 313 & $4 \cdot 03$ & 346 \\
\hline Serine & 509 & 488 & 487 & 5 II & 499 & 4.90 & 564 \\
\hline Glutamic acid & 772 & 803 & 788 & 756 & 780 & $2 \cdot 88$ & 872 \\
\hline Proline & 264 & 239 & 225 & $26 I$ & 247 & $7 \cdot 27$ & 269 \\
\hline Glycine & 176 & 180 & 182 & I 78 & 179 & $I \cdot 46$ & 196 \\
\hline Alanine & 3 I 5 & 318 & 312 & 307 & 3 I 3 & $2 \cdot 13$ & 344 \\
\hline Cystine & 171 & 166 & 136 & 178 & 163 & $9 \cdot 98$ & 104 \\
\hline Valine & 374 & 378 & 389 & $37 I$ & 378 & $3 \cdot 66$ & 260 \\
\hline Methionine & 187 & 165 & 176 & 172 & 175 & $6 \cdot 53$ & I6r \\
\hline Isoleucine & $35^{\circ}$ & 347 & $3^{6} \mathrm{I}$ & 335 & 348 & $3 \cdot 06$ & $32 \mathrm{r}$ \\
\hline Leucine & 543 & 554 & 558 & 537 & 548 & $2 \cdot 19$ & 533 \\
\hline 'Tyrosine & 241 & 259 & 266 & 246 & 253 & $4 \cdot 31$ & $25^{2}$ \\
\hline Phenylalanine & 262 & 256 & 253 & 273 & $26 \mathrm{I}$ & $3 \cdot 48$ & 264 \\
\hline Tryptophan & 123 & I I 7 & 121 & 122 & I2I & $6 \cdot 76$ & - \\
\hline Protein ( $\mathrm{mg} / \mathrm{g}$ dry matter) & 315 & $3 \mathrm{I} 2$ & 285 & $3 \circ 7$ & 305 & & \\
\hline
\end{tabular}

Table 5. Essential amino acids in FAO (1957) provisional pattern and in milk and egg proteins (mg/g nitrogen)

\begin{tabular}{lccccc}
\multicolumn{1}{c}{$\begin{array}{c}\text { FAO } \\
\text { Amino acid }\end{array}$} & $\begin{array}{c}\text { Cow's } \\
\text { Provisional } \\
\text { pattern }\end{array}$ & $\begin{array}{c}\text { Human } \\
\text { milk }\end{array}$ & $\begin{array}{c}\text { milk } \\
\text { (FAO, I970) }\end{array}$ & $\begin{array}{c}\text { Hen's egg } \\
(\text { FAO, I970) } \\
(\text { FAO, I965) }\end{array}$ & $\begin{array}{c}\text { Hen's egg } \\
(\text { FAO, I973) }\end{array}$ \\
Isoleucine & $\mathbf{2 7 0}$ & 295 & 254 & 415 & 338 \\
Leucine & 306 & 596 & 548 & 553 & 535 \\
Lysine & 270 & 487 & 428 & 403 & 439 \\
Total aromatic amino acids & 360 & 633 & 421 & 627 & 578 \\
Total sulphur amino acids & 270 & 208 & 185 & 346 & 353 \\
Threonine & 180 & 278 & 280 & 317 & 296 \\
Tryptophan & 90 & 88 & 105 & 100 & 108 \\
Valine & 270 & 362 & 284 & 454 & 413
\end{tabular}

RESULTS

The protein content of the eggs varied from 407 to $495 \mathrm{~g} / \mathrm{kg}$ dry matter. Table 2 shows the amino acid composition of proteins of eggs from the two breeds of hens.

The nitrogen recovery was measured for each amino acid determination and the mean value was $96 \%$. The results for the different diets, breeds and environments were compared and were statistically analysed by the Student's $t$ test; no significant difference was found. The mean amino acid concentrations of egg protein showed little variation with the breed, environmental conditions or protein content of the diet. The coefficient of variation varied from 2.5 to $9.5 \%$ for lysine, histidine, cystine, tyrosine and phenylalanine and from 7 to $10 \%$ for tryptophan. Results for the amino acid composition of the egg white and the egg yolk are presented in Tables 3 and 4 .

The concentrations of amino acids in the proteins of the whites and yolks showed a consistent pattern. 


\section{DISCUSSION}

Previous work has not established whether or not differences in breed or in the quality or quantity of protein in the diet have a significant influence on the amino acid composition of egg protein. Giving hens diets deficient in methionine, tryptophan, cystine or lysine did not produce any significant changes in the quality of the egg protein (Evans, Davidson \& Butts, I950; Ingram, Cravens, Elvehjem \& Halpin, I95 I $a, b$ ).

It has been reported (Smith, Wilson \& Brown, 1954; Cunningham, Cottril \& Funk, I960; Coppock \& Daniels, I962) that changes in the environmental conditions can cause quantitative changes in the protein content and can alter the ratio of yolk to white of the egg but they do not affect the amino acid pattern.

The present study had a twofold purpose: (I) to verify whether or not the quality of the egg, as revealed by its essential amino acid composition, was independent of external and internal factors which are likely to bring about a physiological change in the animal, and (2) to remove the uncertainties about the amino acid composition of the hen's egg.

Our results have shown a consistency in the amino acid composition of hen's egg protein and also that the composition was not significantly affected by breed or by varying the quantity of dietary protein. However, the amino acid pattern of hen's egg protein was found to differ from that adopted by FAO/WHO (FAO, 1965); values obtained for lysine, total sulphur-containing amino acids and tryptophan were slightly higher (Table 5).

The measured isoleucine content of hen's egg protein $\left(33^{8} \mathrm{mg} / \mathrm{g}\right.$ nitrogen) was significantly lower than that reported by other workers (Mitchell \& Block, 1946; FAO, 1965; Cresta, Périssé, Autret \& Lombardo, 197I) and is probably due to improved analytical procedures. The frequency with which this essential amino acid appears as the first or second limiting acid in practical diets consumed by populations in different parts of the world (Autret, Périssé, Sizaret $\&$ Cresta, I968) is the result of calculations using the high value for the isoleucine content of egg protein reported in the early literature. In fact, the addition of isoleucine to diets in which protein efficiency is theoretically limited by a deficiency of this amino acid produces no significant improvement, except with diets based on millet or sorghum diets; these cereals have a high leucine content and the delaying effect of an excess of leucine on growth is balanced by the addition of isoleucine (Harper, I958). On the other hand, when human milk or cow's milk is used as the reference standard, isoleucine is less frequently found to be limiting. The elimination of isoleucine as a common limiting. amino acid in human diets in which it had appeared to be as limiting as the sulphurcontaining amino acids is in agreement with biological evidence that the latter are the most commonly limiting amino acids in diets for man. This should therefore improve the correlation between the chemical score of proteins calculated from the amino acid pattern of egg protein and results obtained from the biological assay of proteins.

The technical assistance of Mr M. Cappelloni and Mr E. De Siena is gratefully acknowledged. 


\section{REFERENCES}

Association of Official Agricultural Chemists (1965). Official Methods of Analysis. Washington, DC: Association of Official Agricultural Chemists.

Autret, M., Périssé, J., Sizaret, F. \& Cresta, M. (I968). F.A.O. Nutr. Nerusl. 6, I.

Bird, H. R. (1947). Vitams Horm. 5, 163.

Block, R. J. \& Mitchell, H. H. (1946-7). Nutr. Abstr. Rev. 16, 249.

Briggs, G. M., Spivey, M. R., Keresztsesy, J. C. \& Silverman, M. (1952). Proc. Soc. exp. Biol. Med. 8I, I I 3 .

Coppock, J. B. M. \& Daniels, N. W. R. (1962). F. Sci. Fd Agric. 13, 459.

Cresta, M., Périssé, J., Autret, M. \& Lombardo, E. (197I). Annls Nutr. Aliment. 25, 6r.

Cunningham, F. E., Cottril, O. J. \& Funk, E. M. (1960). Poult. Sci. 39, 300.

Edwards, C. H., Carter, C. P. \& Outland, C. E. (1955). F. agric. Fd Chem. 3, 952.

Evans, J. E., Davidson, J. A. \& Butts, H. A. (1950). Poult. Sci. 29, 104.

FAO (1957). F.A.O. Nutr. Stud. no. 6 .

FAO (1965). F.A.O. Nutr. Mtg Rep. Ser. no. 37. (Tech. Rep. Ser. Wld Hlth Org. no. 301).

FAO (1970). F.A.O. Nutr. Stud. no. 24.

FAO (1973). F.A.O. Nutr. Mtg Rep. Ser. no. 52.

Harper, A. E. (1958). Ann. N.Y. Acad. Sci. 69, 1025.

Ingram, G. R., Cravens, W. W., Elvehjem, C. A. \& Halpin, J. G. (r95 r a). Poult. Sci. 30, 426.

Ingram, G. R., Cravens, W. W., Elvehjem, C. A. \& Halpin, J. G. (I95 I b). Poult. Sci. 30, 43 I.

Lunven, P. (1963). Qualitas Pl. Mater. veg. 1o, 276.

Mitchell, H. H. \& Block, R. J. (1946). F. biol. Chem. r63, 599.

Moore, S. \& Stein, W. H. (1951). Y. biol. Chem. r92, 663 .

Rutgers University Bureau of Biological Research (1950). Cooperative determination of the nutritive value of six selected protein food sources. New Brunswick: Rutgers University Press.

Schram, E., Moore, S. \& Bigwood, E. J. (1954). Biochem. F. 57, 33.

Smith, A. H., Wilson, W. O. \& Brown, J. G. (1954). Poult. Sci. 33, 898 . 